\title{
The Influence of Education and Environmental Support on Entrepreneurial Intentions
}

\author{
Submitted 14/08/20, 1st revision 17/09/20, 2nd revision 06/10/20, accepted 30/11/20
}

\section{Hussein-Elhakim Al Issa ${ }^{1}$}

\begin{abstract}
:
Purpose: Promoting entrepreneurship requires a dual policy approach that must emphasize the present and future vision of entrepreneurship. With more attention given to the present, the current study aims to fill this gap by examining the indirect effect of environmental support and the direct effect of education on entrepreneurial intentions among female university students.

Approach/Methodology/Design: Data were collected from 184 valid responses finalyear students in Omani universities. Structural equation modeling by means of partial least square bootstrapping resampling was used for hypotheses testing of the 184 usable responses.

Findings: Statistically significant positive relationship was found between entrepreneurial education and intentions and between support and education. Education played an important mediating role in the relationship between support and intentions. However, structural support had no effect on education and intentions.

Practical Implications: With large investments made in education, policymakers can focus efforts more precisely in utilize the findings on the ability of education and environmental support to increase the intentions of graduates in the field of entrepreneurship.

Originality/Value: The examination of entrepreneurial intentions using environmental support and education as indirect and direct predictors is unprecedented. These results reduce the search for antecedents of entrepreneurial intentions and provide educators with a more precise point for intervention.
\end{abstract}

Keywords: Entrepreneurial intentions, universities, female students, environmental support, education, Oman.

JEL classification: L26.

Paper Type: Research article.

\footnotetext{
${ }^{1}$ Department of Management, College of Business Administration, A'Sharqiyah University, Ibra,Oman, e-mail: hussein.alissa@asu.edu.om
} 


\section{Introduction}

The importance of entrepreneurship is evident in many studies. In developed countries, a significant portion of the economic growth rate can be attributed to entrepreneurs (Al Issa, 2020a; Sobel, 2008; Valliere and Peterson, 2009). A recent study found that early-stage, opportunity-driven, and necessity-driven entrepreneurship had a significantly positive impact on economic growth for the study's entire sample of 22 European countries (Stoica, Roman, and Rusu, 2020). Another study found that entrepreneurship explains the positive variation in the growth of African countries (Omoruyi, Olamide, Gomolemo, and Donath, 2017). Entrepreneurship among young women deserves special attention, however. A GEM report from 2019 shows that approximately 231 million women were starting or running new businesses in 59 countries. The age group in which starting a business is most prevalent is 25-44 (GEM 2019); thus, the current study focuses on students under the age of 25 to understand the factors that affect their entrepreneurial intentions (EI). Since the inspiration of entrepreneurship is vital to kindle its growth and since the instruction given in a university typically affects the career choices of students, it is important to determine why graduates choose an entrepreneurial career.

It is important to study entrepreneurship as a practical alternative to traditional employment among women in the Middle East. In Oman, the unemployment rate for women was $13 \%$ (males $1.63 \%$ ) in 2019, up from $8.9 \%$ (males 3.9\%) in 1991 according to the World Bank report (The Global Economy, 2020). To circumvent the problems caused by this trend, authorities are attempting to shift graduates' attention towards entrepreneurial activities to encourage labor empowerment and development in the region (Ibrahim et al., 2017; Mehtap et al., 2017).

A recent study by the Global Entrepreneurial Monitor (GEM, 2019) found that the lowest percentage of female business owners in the world is found in the Middle East and North Africa (MENA) at 4.5\%. A GEM study also revealed that the more educated that women are, the less likely they are to be entrepreneurial except for those in lower-income nations. The reason for this phenomenon is that women with more education in wealthier countries have more options for employment. The importance of the state context is central to the state's influence on the female entrepreneurial force with their varying duties (Bruin et al., 2007; Jabeen and Faisal, 2018; Venugopal, 2016). Because of this, it is quite compelling to study environmental support (ES) factors as a possible antecedent of female graduates' choice to become entrepreneurs.

Learning about the factors that can affect one's decision to start a business can result in discoveries that have an influence on economic growth and development. Many past studies have identified factors that influence Entrepreneurial Intentions (EI), such as personality traits or characteristics (Adekiya and Ibrahim 2016; McClelland, 1961; Neneh, 2019; Norena-Chavez and Guevara, 2020), contextual factors 
(Reardon 1991; Salami 2007; Schmutzler, Andonova, and Diaz-Serrano, 2019), and institutional and environmental factors (Shi, Yao, and Wu, 2019; Turker and Selcuk, 2009). While there are several studies that propose a positive association between Entrepreneurial Education (EE) and EI (Kautonen, van Gelderen, and Fink 2015; Otache, Umar, Audu, and Onalo, 2019; Norena-Chavez, 2020), there is also evidence of a negative, deterring effect of EE on these intentions (Nowinski et al., 2019; Oosterbeek et al., 2010). These mixed results point to environmental contingencies as conditions to the desired outcome of education boosting intentions (Shi et al., 2019; Walter and Dohse, 2012). However, little research has been devoted to examining the roles that educational institutions and relational and structural factors play in students' intentions to start and manage a venture start-up upon completing their education.

Furthermore, while substantial work has been done on entrepreneurship education in developed countries (Al Issa et al., 2020; Fayolle, Lamine, Mian, and Phan, 2020; Iakovleva et al., 2011; Walter and Block, 2016), the topic has received limited attention in the Gulf Cooperation Council (GCC). Ibrahim, Devesh, and Ubaidullah (2017), Elali, and Al Yacoub (2016), and Faisal, Jabeen, and Katsioloudes (2017) are among the few researchers who have explored this topic in the region. Even though they discovered positive results, due to the variation in the EE methods among universities throughout different countries (Matlay and Jones, 2011), further studies are warranted.

For ES to have an impact on the encouragement of female graduates towards a rewarding and appealing future as entrepreneurs, a solid EE system must be in place to prepare them for independent livelihoods and promising careers. Building on the assumptions proposed above, this study intends to achieve the following research objectives:

1) To investigate the relationship between entrepreneurial education and intentions among female students.

2) To examine the relationship between environmental support and entrepreneurial education among female students.

3) To determine the intervening effect of entrepreneurial education on the relationship between environmental support and entrepreneurial intentions among female students.

\section{Literature Review}

\section{Theoretical Foundation:}

The growth of female-owned firms may be only one representation of a changing society, as opposed to being caused by any real innate distinction between the genders' abilities or drives. Therefore, if this is true, then the characteristics of female entrepreneurs in the future will still correspond to changes in their conditions and will move even closer to the characteristics of male entrepreneurs. Two 
important ways to look at gender equality are through the lenses of psychodynamic theory and social learning theory (Mcleod, 2016, 2017). Psychodynamic theories emphasize unconscious motivations, especially those caused by events involving and stories from early caretakers. Gender depends on a child's mindfulness of his or her recognition with a caregiver of the same sex. Social learning theory, on the other hand, stresses the importance of learning from the environment. Gender is a role that the child learns to play by observing and imitating a parent of the same sex. However, men and women are different biologically, and that difference accounts for their differing natures and work choices. Consequently, any imposed equality of outcomes is unjustified and misguided. For example, men are more likely than women to work in the STEM (science, technology, engineering, and mathematics) fields, and they tend to be more risk-seeking and thus more likely to take on entrepreneurial careers than women (Peterson, 2020). Further, Gupta, Turban, and Bahwe (2008) found that widely held gender stereotypes influence intention.

Figure 1. Research Framework

Source: Own study.

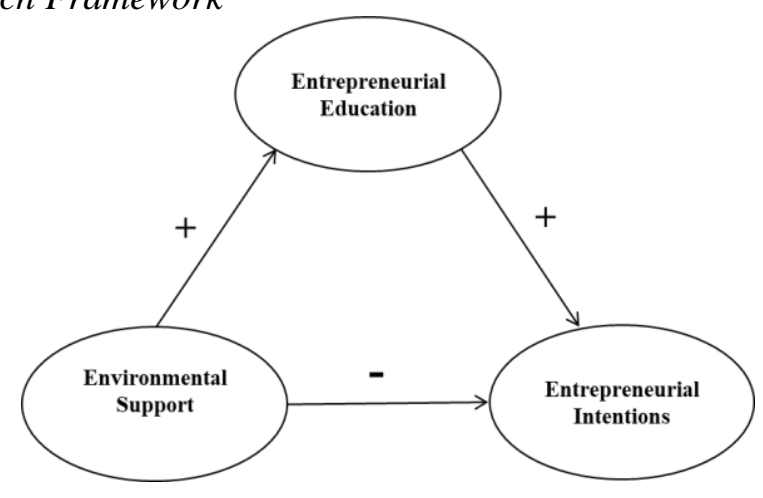

The research framework illustrating the hypothesized relationships between ES, EE, and EI is presented in Figure 1. The hypothesized relationships are supported by Shapero and Sokol's (1982) entrepreneurial event (SEE) theory and the theory of planned behavior (TPB) by Ajzen (1991). SEE proposed that the intention to start a business depends on the inclination to act on opportunities and on perceptions of feasibility and desirability. Perceptions of feasibility and desirability are products of social environments and cultures that determine the actions taken. Partaking in entrepreneurship training can influence a student's perceived feasibility of future entrepreneurship.

Individuals' values, attitudes, and feelings are also shaped by their educational and relational environments, such as family, peers, and professional and educational influences, which will affect their perceived desirability of entrepreneurship. In other words, perceived feasibility and desirability are products of cultural and social environments, which can be impacted by education, social support, cultural values, family, and availability of financial resources. According to the TPB, it is assumed 
that becoming an entrepreneur is a consciously planned behavior (Ajzen, 1991). If individuals' attitudes about entrepreneurship are positively influenced by education, then their entrepreneurial intentions will also be.

Interestingly, previous studies have identified the variables used in the current study as possible barriers to women's entry into entrepreneurship, namely, educational barriers, infrastructure (support), and societal and cultural barriers (hostile values and attitudes) (El-Namaki and Gerritson, 1985; Birley, 1987). A recent study, for instance, found that in the UAE (Bastian, 2018), expatriate women are influenced by push factors such as financial security, lack of job opportunities and low income, while local women are more influenced by independence, social status and selfesteem (Itani et al., 2011). Similarly, Faizal, Jabeen, and Katsioloudes (2017) found that the main obstacles that adversely impact the entrepreneurial progress of women in GCC countries are lack of environmental and relational support, culture and religion, and gender bias.

However, in developing countries, women are more likely to be influenced by push factors (necessity driven); in the GCC, this might not be true since men have more secure jobs to support the family. Therefore, GCC female entrepreneurs are driven by pull factors (personal challenge driven), which are qualities more often associated with women from middle and upper incomes. Typically, it is believed that men have stronger EI (Zhao, Seibert, and Hills 2005). However, the current research proposes that this gender difference is only as good as the level of ES and the quality of EE that each gender receives. EE and encouragement are what women entrepreneurs need, like many other underprivileged or minority groups in society.

\section{Entrepreneurial education and intentions:}

Researchers declare that entrepreneurship can be taught (Hahn, Minola, Van Gils, and Huybrechts, 2017; Kuratko 2005; Turner and Gianiodis, 2018). However, it is impossible to make a definite statement about the teachability of any other discipline (Ronstadt, 1985). For college students, EE has a strong impact on EI (Bae et al., 2014; Fayolle, Gailly, and Lassas-Clerc 2006). Much research suggests that EE promotes EI and therefore promotes entrepreneurial activity (Díaz-Casero et al., 2017; Peterman and Kennedy, 2003; Sánchez, 2013). For example, a study of 117 female students conducted in GCC countries revealed that the entrepreneurial interests of female students in Dubai are positively affected by how universities develop these interests and by the education and training provided (Gallant, Majumdar, and Varadarajan, 2010). Other studies have shown the potential of EE to stimulate the increased perceived relevance of formal education and therefore to strengthen motivation and engagement and lessen boredom and dropout (Farhangmehr et al., 2016; Moberg, 2014; Son et al., 2013).

However, there is some indication of a negative, deterring influence of EE on intentions (Nowinski et al., 2019; Oosterbeek et al., 2010). Students seek EE because of their interest in the subject or as a potentially useful protection from 
career uncertainty (Venkatraman, 1994). The new school of thought states that "entrepreneurial success is a function of a viable combination of human, venture, and environmental conditions" (Rondstat, 1985). In developing countries, there is a lack of research relating EE with EI (Gaddam, 2008; Nabi and Linan, 2011; Solesvik et al., 2013). Therefore, in the current study, the following hypothesis is proposed:

\section{H1. Entrepreneurial education (EE) is significantly related to entrepreneurial intentions (EI).}

\section{Environmental support, entrepreneurial education, and intentions:}

The rationale behind the direct relationship between ES (educational, relational, and structural) and EE proposed is that when a person perceives support for entrepreneurship, she is then encouraged to want to learn more about entrepreneurship. For instance, Arenius and Minniti (2005) suggested clustering the factors affecting entrepreneurial decisions into three core clusters: demographic and economic features of the entrepreneur, perceptual variables grounded in subjective decisions made by the entrepreneurs, and aggregate variables of the surrounding environment. There is a need to create favorable environments for entrepreneurship through education, so careful attention must be given to devise a combination of human, venture, and environmental conditions that are able to prepare potential entrepreneurs for a successful career (Al Issa, 2020b; Son and Noja, 2013).

According to Ronstadt (1985), this combination is a function of not only "entrepreneurial know-how" but also "entrepreneurial know-who." Thus, important skills to learn are "Environmental Assessment Skills". These statements point to the importance of ES factors at play. As universities recognized their important role in educating students for entrepreneurship, they made changes in their organization and culture to improve their ES for opportunities in teaching, research, and social outreach (Mandrup and Jensen, 2017; Villarreal and García, 2004).

There is some negative evidence, however, that show deterring effects of EE on EI (Oosterbeek et al., 2010), perhaps indicating that factors involving environmental conditions affect the outcomes of EE (Walter and Dohse, 2012). The importance of institutional and social contexts is documented, as these contexts set limits on the opportunities and activities available for the type and degree of entrepreneurship within the context (Welter et al., 2011). For example, a study investigated the relationships between contextual factors and entrepreneurship found that intentions to start a business are linked to educational, relational, and structural support (Turker et al., 2009), perceived barriers and support factors (Luthje and Franke, 2003), the appeal of entrepreneurship among students (Keat, Selvarajah, and Meyer, 2011; Wang and Verzat, 2011), and entrepreneurship image and university support (Autio et al., 1997). In their study to identify barriers to female entrepreneurship, Raghuvanshi, Agrawal, and Ghosh (2017) carried out a decision-making trial and evaluation laboratory technique to find a connection. They identified five important barriers, namely, "lack of education, experience and training opportunities, spatial 
mobility and lack of family support; lack of institutional support, lack of entrepreneurial management; and problems in acquiring financial resources".

Many scholars agree that entrepreneurial career development can be supported by universities through the engagement of role models, provision of a support network, and business planning competitions (Nasiru, Keat, and Bhatti, 2015; Turker and Selcuk, 2009; Franke and Luthje, 2004). Díaz-Casero et al. (2017), for example, found that the university context has a positive and significant effect on EI directly, as well as indirectly through EE. Another example of the influence of universities that could lead to the pursuit of EE is given by Autio et al., 1997. They surveyed technology students from four different countries and found that their career choices and entrepreneurial convictions were affected by seeing entrepreneurship as a career option and by the support they received from the university environment.

Perceived structural support (PSS) and perceived relational support (PRS) can inspire or dishearten the level of involvement with entrepreneurial activity (Mueller and Thomas, 2001; Pruett et al., 2009). Previous research found that a supportive environment can kindle entrepreneurship by giving access to information (Sandhu et al., 2011) and networking opportunities (Al-Alak and Al-Haddad, 2010; Caputo et al., 2016). Other scholars advocated the benefits and significance of family support in the creation of entrepreneurial endeavors (Aldrich and Cliff, 2003; Chang et al., 2009). For example, Jabeen et al. (2015) reported that support from family members influences the entrepreneurial success of Emirati women. These researchers recognize that "supportive networks of relationships" are created by family, societal, and personal factors (El-Sokari et al., 2013). They conclude that Emirati women start businesses because of "pull reasons" such as finding purpose and independence (Tlaiss, 2015). Another study, by Hechavarría and Ingram (2019), found that women tend to choose an entrepreneurial career when the environment has "low barriers to entry, supportive government policy towards entrepreneurship, minimal commercial and legal infrastructure, and a normative culture that supports entrepreneurship."

External conditions can encourage or deter internal conditions that are related to the individual. Structural support is the mechanism used for influencing entrepreneurship economically and politically. If the public and private players in the market are keen on enhancing the entrepreneurial environment with policies and measures that create opportunities and remove barriers in the market, then EE should be among the factors positively affected by these policies and measures. Structural support can influence education directly by funding EE and indirectly through the support programs available to aspiring entrepreneurs designed to develop their careers in entrepreneurship and to teach them about markets, financing, and the government programs at their disposal. Towards this end, the current study put forth the following four hypotheses, one of which was the main hypothesis for the ES-EI relationship. The following three hypotheses were the sub-hypotheses formulated between each ES dimension and EI: 
H2. Environmental support (ES) is significantly related to EE.

$H 2 a$. Perceived educational support (PES) is significantly related to EE.

$H 2 b$. Perceived relational support (PRS) is significantly related to EE.

H2c. Perceived structural support (PSS) is significantly related to EE.

Few studies have explored the impact of ES on EE and our understanding of the indirect effect of PES on EI among female students. Some studies did, however, find that university support indirectly influences EI (Karimi et al., 2017; Shi et al., 2019). Maina (2011), for example, showed that college support of entrepreneurial experiences indirectly impacted intentions through self-efficacy and perceptions of desirability. More recently, Díaz-Casero et al. (2017) found that the university context has a positive and significant effect on EI directly, as well as indirectly through EE. From the above discussion, the following four hypotheses were formulated, one of which was the main hypothesis for the EE-mediated ES-EI relationship. The remaining three hypotheses were sub-hypotheses formulated for the mediation of EE on the relationships between each of the ES dimensions and EI:

\section{H3. EE significantly mediates the relationship between ES and EI.}

$H 3 a$. EE significantly mediates the relationship between PES and EI.

$H 3 b$. EE significantly mediates the relationship between PRS and EI.

$H 3$ c. EE significantly mediates the relationship between PSS and EI.

\section{Methods}

Population, Sample, and Research Instruments:

The population for the current study was female students in the last year of their business program at two small colleges, one state and one private in the North Sharqiyah region of Oman. The questionnaires were distributed to population sizes of approximately 151 and 187 , respectively. Using convenience sampling, 196 questionnaires were collected, 184 of which were usable. The data collection process involved administering questionnaires and a cover letter to respondents through pollsters, after which data were analyzed using two SPSS models and the SmartPLS software.

A structured questionnaire was used consisting of 20 items gauged on a five-point Likert scale ranging from 5 strongly disagree to 1 strongly agree. According to the results, $58 \%$ of the respondents had work experience. The instrument used to measure EI contained 3 items and was adapted from the work of Fragoso, RochaJunior, and Xavier, 2020 based on Linan and Chen, 2009. The EI construct was used to represent the behavior perceived among college students who were intending to create a new venture after finishing their studies (Ladd, Hind, and Lawrence, 2019). The measure used for EE was adopted from Fragoso et al. (2020) and based on Walter and Block (2016) and had 7 items. The EE construct was used to represent the practice of providing persons with the aptitude to identify business opportunities and with the knowledge, skills, and attitudes to exploit those opportunities (Jones 
and English, 2004). EE usually consists of all related entrepreneurship courses covering various areas of small business management and entrepreneurship courses that are vital for entrepreneurial start-ups (Zhao, Seibert, and Hills, 2005; Walter and Block, 2016). The ten items that measured ES were adapted from Turker and Selcuk (2009). The ES construct was used to represent PES, PRS, and PSS. To reduce measurement error, a pilot test was carried out on a sample of 40 respondents, followed by some minor alterations of the questionnaire to account for cultural and language effectiveness. This was deemed necessary as respondents were provided with both English and Arabic questionnaires to choose from which meant that a back-to-back translation must be carried out as recommended by Craig and Douglas (2005).

\section{Results}

For the data analysis, SPSS v20 was employed to handle missing data, outliers, normality, linearity, multicollinearity, and homoscedasticity. All assumptions and measurement assessments were examined, as were the results of the confirmatory factor analysis, the common method variance (CMV), and the normality. There were no indications of nonresponse bias per an independent samples t-test comparing the study's variables. All p values were above .05 in the t-test results and showed no significant difference between early and late responders (Pallant, 2013). The output from SPSS was checked for outliers by looking at the Mahalanobis distances for values greater than the critical chi-square value (18.47) using the three independent variables as the degrees of freedom. There was one value at 19.19, and given the size of the data file, the researcher decided to keep it since it was the only one exceeding the critical value and was only slightly above this value, which confirmed the absence of outlier observations (Tabachnick and Fidell, 2007).

Table 1. Reliability and validity - Entrepreneurial Intentions

\begin{tabular}{lccc}
\hline Variables/Indicators & Loadings & AVE & CR \\
\hline Entrepreneurial Intentions & & 0.786 & 0.917 \\
ES1 & 0.914 & & \\
ES2 & 0.872 & & \\
ES3 & 0.873 & &
\end{tabular}

Source: Own study.

Table 2. Reliability and validity - Environmental Support

\begin{tabular}{lccc}
\hline Variables/Indicators & Loadings & AVE & CR \\
\hline Perceived educational support & & 0.705 & 0.905 \\
ES1 & 0.877 & & \\
ES2 & 0.832 & & \\
ES3 & 0.836 & & \\
ES4 & 0.813 & 0.810 & 0.895 \\
Perceived relational support & & & \\
ES5 & 0.885 & &
\end{tabular}


ES6

Perceived structural support

ES7

ES8

ES10
0.915

0.842

0.663

0.793

Source: Own study.

0.593

0.812

The effects of common method variance were mitigated against by safeguarding the anonymity of the surveyed students, decreasing evaluation fear, and clarifying survey items by interpreting each indicator. Along these lines, Harman's single factor test was used, and the first factors explained less than $50 \%$ of the total variance as recommended by MacKenzie and Podsakoff (2012). After the retrieval of all the questionnaires, a data cleaning process showed that less than $5 \%$ of the values were missing per indicator, so these values were replaced using SPSS's Expectation-Maximization function. Normality was established for all the variables using the Q-Q plot, which was nearly a straight line, and the histogram was nearly a bell shape. The detrended normal Q-Q graphical showed no clustering of points, with most of the points accumulating near zero. The VIF (variance-inflated factor) was below 5 , at $1.706,2.027,1.702$, and 1.825 and the tolerance values were above .20 , at $.586, .493, .588$, and .548 , for EE, PES, PRS, and PSS, respectively, which indicated that there were no multicollinearity issues.

Table 3. Reliability and validity -Entrepreneurial Education

\begin{tabular}{lccc}
\hline Variables/Indicators & Loadings & AVE & CR \\
\hline Entrepreneurial Education & & 0.534 & 0.888 \\
EE1 & 0.749 & & \\
EE2 & 0.780 & & \\
EE3 & 0.814 & & \\
EE4 & 0.783 & & \\
EE5 & 0.700 & & \\
EE6 & 0.673 & & \\
EE7 & 0.593 & &
\end{tabular}

Source: Own study.

Table 4. Discriminant Validity (Fornell-Larcker Criterion)

\begin{tabular}{llllll}
\hline & Education & Intentions & PES & PRS & PSS \\
\hline Education & 0.735 & & & & \\
Intentions & 0.258 & 0.886 & & & \\
PES & 0.643 & 0.184 & 0.849 & & \\
PRS & 0.023 & 0.108 & 0.313 & 0.9 & \\
PSS & 0.314 & 0.144 & 0.491 & 0.45 & 0.827
\end{tabular}

Source: Own study. 
Table 5. Discriminant Validity (HTMT)

\begin{tabular}{llllll}
\hline & Education & Intentions & PES & PRS & PSS \\
\hline Education & & & & & \\
Intentions & 0.276 & & & & \\
PES & 0.719 & 0.183 & & & \\
PRS & 0.074 & 0.144 & 0.391 & & \\
PSS & 0.319 & 0.188 & 0.59 & 0.772 &
\end{tabular}

Source: Own study.

Next, the PLS-SEM measurement model was constructed for confirmatory factor analysis. Both reliability and validity were assessed at the indicator and construct level. Subsequently, the elimination of only one indicator (ES9), which had a loading <.40. Tables 1,2 , and 3 display the satisfactory composite reliability ranges of .917 to $.905, .895,812$, and .888 for the five constructs, namely, EI, PES, PRS, PSS, and EE, respectively. Convergent validity was established with the average variance extracted (AVE), which surpassed .5 as per the rule of thumb by Hair et al. (2017). The evaluation of the measurement model began by inspecting the outer model, and the evaluation of the discriminant validity. The Fornell-Larcker's criterion (1981) resulted in square roots for all AVEs that were higher than the interconstruct correlations, so discriminant validity at the construct level was also established (Table 4). Discriminant validity was also checked further using heterotrait-monotrait ratio (HTMT), which showed a high HTMT ratio at .961 for PSS with PRS, and so item ES7 was eliminated since it had a low correlation with other items in the same construct. This resulted in improved HTMT values as in Table 5, all of which were below the recommended .90 (Gold, and Arvind Malhotra, Segars, 2001; Teo et al., 2008).

\section{Figure 2. Structural Model}

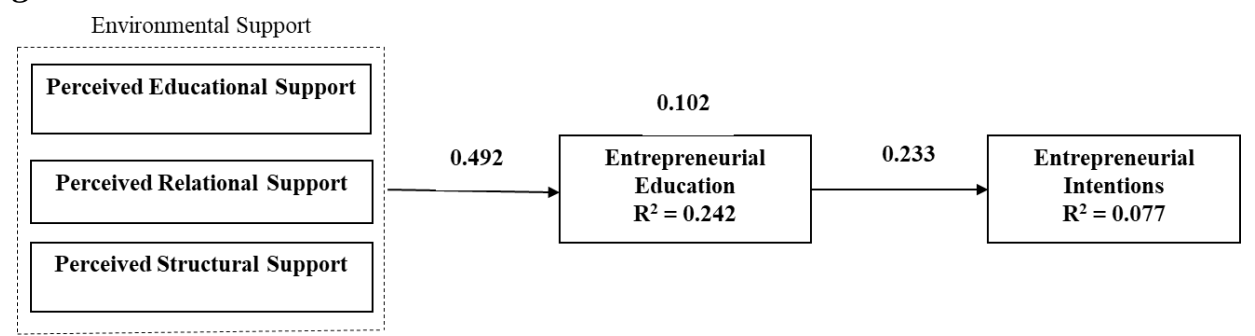

Source: Own study.

To assess the structural model, this study adhered to the six main steps of the statistical procedure recommended by Hair et al. (2017) in Figure 2. The first step was to check for collinearity issues. The VIF (variance-inflated factor) was below 5, and the tolerance values were above .20 . Next, the results of the hypotheses tests were as displayed in Table 6. The PLS-SEM bootstrapping output at 5000 subsamples showed four hypotheses accepted at $\mathrm{p}<.01$, while three hypotheses 
were accepted at $p<.05$, and two were rejected. The third step in evaluating the structural model is to assess the value of $\mathrm{R}^{2}$. The coefficient of determination $\mathrm{R}^{2}$ for EI was 0.077 (0.066 R2 Adjusted), and for EE, it was 0.242 (0.238 R2 Adjusted) in the ES unidimensional model (Figure 2). The $\mathrm{R}^{2}$ value was $0.078(0.057 \mathrm{R} 2$ Adjusted) for EI and 0.453 (0.444 R2 Adjusted) for EE in the ES multidimensional model.

The following step was to assess $\mathrm{f}^{2}$. The effect sizes $\left(\mathrm{f}^{2}\right)$ for the constructs were small at 0.004 for ES with EI and large at 0.044 for EE with EI in the ES (Kenny, 2016). Next, the blindfolding procedure was performed to assess the predictive relevance $\mathrm{Q}^{2}$ of the endogenous latent construct indicators, which was .04 (omission distance $\mathrm{D}=7$ ) for $\mathrm{EI}$ and 0.118 for EE when ES is unidimensional. Finally, effect size $\mathrm{q}^{2}$ were assessed to find the predictive relevance for the endogenous construct. Accordingly, $\mathrm{q}^{2}$ values were calculated for ES, and these values for $\mathrm{EE}$ and EI were 0.001 and 0.025 , respectively. The values of $\mathrm{q}^{2}$ reflecting small, medium, and large effects are 0.02, 0.15, and 0.35, respectively (Hair et al., 2017).

Table 6. Structural estimates

\begin{tabular}{|l|c|c|c|c|}
\hline Hypothesis & $\begin{array}{c}\text { Standard } \\
\text { beta }\end{array}$ & $\begin{array}{c}\mathbf{t}- \\
\text { statistics }\end{array}$ & $\begin{array}{c}\text { P } \\
\text { Values }\end{array}$ & Decision \\
\hline $\mathrm{H} 1 . \mathrm{EE} \rightarrow \mathrm{EI}$ & 0.233 & 2.635 & 0.008 & Accept \\
\hline $\mathrm{H} 2 . \mathrm{ES} \rightarrow \mathrm{EE}$ & 0.492 & 8.948 & 0.000 & Accept \\
\hline $\mathrm{H} 2 \mathrm{a} . \mathrm{PES} \rightarrow \mathrm{EE}$ & 0.671 & 12.336 & 0.000 & Accept \\
\hline $\mathrm{H} 2 \mathrm{~b} . \mathrm{PRS} \rightarrow \mathrm{EE}$ & -0.226 & 3.257 & 0.001 & Accept \\
\hline $\mathrm{H} 2 \mathrm{c} . \mathrm{PSS} \rightarrow \mathrm{EE}$ & 0.086 & 1.183 & 0.237 & Reject \\
\hline $\mathrm{H} 3 . \mathrm{ES} \rightarrow \mathrm{EE} \rightarrow \mathrm{EI}$ & 0.115 & $2.418^{*}$ & 0.016 & $\begin{array}{c}\text { Accept (indirect-only - } \\
\text { full mediation) }\end{array}$ \\
\hline $\mathrm{H} 3 \mathrm{a} . \mathrm{PES} \rightarrow \mathrm{EE} \rightarrow \mathrm{EI}$ & 0.179 & $2.388^{*}$ & 0.017 & $\begin{array}{c}\text { Accept (indirect-only }- \\
\text { full mediation) }\end{array}$ \\
\hline $\mathrm{H} 3 \mathrm{~b} . \mathrm{PRS} \rightarrow \mathrm{EE} \rightarrow \mathrm{EI}$ & -0.060 & $2.009^{*}$ & 0.045 & $\begin{array}{c}\text { Accept (indirect-only - } \\
\text { full mediation) }\end{array}$ \\
\hline $\mathrm{H} 3 \mathrm{c} . \mathrm{PSS} \rightarrow \mathrm{EE} \rightarrow \mathrm{EI}$ & 0.023 & 1.031 & 0.303 & Reject \\
\hline
\end{tabular}

Note: *Accept at $5 \%$ significance level

Source: Own study.

\section{Discussion and Conclusions}

The present study set out with the aim of assessing the relationship between EE and EI and the relationship between ES and EE to investigate the mediating role of EE in the relationship between ES and EI. The first research objective was to examine EEEI association. Parallel to that, H1 was tested and supported. This means that the right program of entrepreneurial education is associated with entrepreneurial intentions among female students in business schools. The model explained $7.7 \%$ of the variance in EI. This is in line with past studies (Díaz-Casero et al., 2017; Sánchez, 2013). Table 6 displays the results. 
The second research objective sought to investigate the ES-EE association. The corresponding H2 was accepted (standard beta $=0.492$, $\mathrm{t}$-statistic $=8.948, \mathrm{p}<.000$ ). The model explained $24.2 \%$ of the variance in EE. A supporting environment from the college, family, friends, and system surrounding a student can enhance the effect of the EE for EI.

The results also showed that $\mathrm{H} 2 \mathrm{a}$, namely, PES-EE association was significant (standard beta $=0.671, \mathrm{t}$-statistic $=12.336, \mathrm{p}<.000$ ). H2b was also accepted for the PRS-EE association and was negatively significant. PRS support through reassurance, moral support, and sometimes funding but these can encourage or discourage the level of entrepreneurial activity and education. This is because students' sense that education takes away from the financial support or even delays their start-up aspirations.

Hypothesis H2c was rejected. SS, through its economic and political mechanisms, was not found to affect EE. This might be because women in Oman might not perceived any structural and governmental support in place for their effective EE. It might in place for actual entrepreneurs but not students. Moreover, the students' perception indicated that they were unsure of whether governmental support in the Middle East and North Africa a formality or is it real (Bastian, 2018).

The third objective was tested through $\mathrm{H} 3$ for the mediating role of $\mathrm{EE}$ in the ES-EI association, which was accepted. H3a that tested EE mediating role in the PES-EI association was also accepted. These results are in line with the long-standing impact of environmental factors on entrepreneurial outcomes years (Karimi et al., 2017; Turker and Selcuk, 2009). The motivation behind examining EE as a mediator was that multidimensional ES had been an established construct (Díaz-Casero et al., 2017; Turker and Selcuk, 2009), and so each dimension was presumably enough to establish a standalone effect on EE and EI.

The accepted $\mathrm{H} 3 \mathrm{~b}$ revealed that EE negatively mediates the PRS-EI association. An explanation for this is that students are convinced that, if they obtain EE, they will not need the PRS that would then lead them to intend to start a business. Lastly, H3c was rejected because women do not think that this support would be available to them if they took part in EE or would not bring them closer to PSS. A solution could be to make EE more informative of PSS available and how entrepreneurs can make use of it for a successful career in entrepreneurship.

The current study fills a gap in the scarce literature exploring predictors of entrepreneurial intentions among female students in GCC countries. The findings revealed that the support and education have strong influences on intentions. This does not discount the importance of other contextual or internal factors at play, such as culture, business experience, and family background. While various antecedents of EI have been studied in various contexts, the examination of EI with ES and education as predictors and mediators is unprecedented. Another implication is 
regarding the large investments made in education, policymakers can utilize findings that verify the value of EE to increase the EI and on the effect of environmental support. An implication for educational institutions, family and friends is that PRS of women might discourage them from pursuing EE due to an urgent drive to start a business immediately and to forego EE because of a lack of perceived value. Lastly, there might be a lack of overall continued support for females in and out of school. This presents an opportunity for EE programs to reach out to females by providing role modeling, business model competitions, workshops, and mentoring (Cochran, 2019; Peterson and Limbu 2010).

A limitation to the current is the small number of respondents $(n=184)$ from a single region in Oman. Another limitation is the use of self-rating scales, which tend to contribute to response bias. The cross-sectional nature of the study makes the findings difficult to generalize.

Future research is advised to include a bigger sample and possibly a longitudinal study that offer the advantage of tracking changes over time. A future study could explore the effects of age, business experience, and gender on EI. Other research could explore deeper-rooted values in the Arab world. The influences on a female's choice to pursue an entrepreneurial career in the Arab world have profound roots in cultural values and beliefs. Aspects of the strict management practices in Arab countries could be investigated to discover how they are nurtured by a mixture of family and tribal norms and organizational structures (Al-Kubaisy, 1985). Future research can also explore assertions as stated by House et al. (2004), in Arab countries, gender inequality is not minimized much by the collective population, and Hofstede (2001) who considers MENA countries to follow the standard pattern in which the father earns an income and the mother cares for the family.

\section{References:}

Adekiya, A.A., Ibrahim, F. 2016. Entrepreneurship intention among students. The antecedent role of culture and entrepreneurship training and development. The International Journal of Management Education, 14(2), 116-132.

Al-Alak, B., Al-Haddad, F. 2010. Effect of gender on the success of women entrepreneurs in Jordan. Interdisciplinary Journal of Contemporary Research in Business, 1(12), 42-62.

Aldrich, H.E., Cliff, J.E. 2003. The pervasive effects of family on entrepreneurship: toward a family embeddedness perspective. Journal of Business Venturing, 18(5), 573-596.

Al Issa, H. 2020a. The impact of improvisation and financial bootstrapping strategies on business performance. EuroMed Journal of Business. https://doi.org/10.1108/EMJB-032020-0022

Al Issa, H. 2020b. When grit leads to success: the role of individual entrepreneurial orientation. Business: Theory and Practice, 21(2), 643-653. https://doi.org/10.3846/btp.2020.12346

Al Issa, H., Abdelsalam, M.K., Omar, M.M.S. 2019. The effect of entrepreneurial selfefficacy on persistence: Do financial literacy and entrepreneurial passion matter? Polish 
Journal of Management Studies, 20(2), 60-72.

https://doi.org/10.17512/pjms.2019.20.2.05

Aguinis, H., Beaty, J.C., Boik, R.J., Pierce, C.A. 2005. Effect size and power in assessing moderating effects of categorical variables using multiple regression: A 30-year review. Journal of Applied Psychology, 90, 94-107.

Ajzen, I. 1991. The theory of planned behavior. Organizational behavior and human decision processes, 50(2), 179-211.

Al-Kubaisy, A. 1972. Theory and Practice of Administrative Development in a New Nation. Dissertation Abstracts International, A32, 5873-A.

Arenius, P., Minniti, M. 2005. Perceptual variables and nascent entrepreneurship. Small business economics, 24(3), 233-247.

Autio, E., Keeley, R.H., Klofsten, M., Ulfstedt, T. 1997. Entrepreneurial intent among students: testing an intent model in Asia, Scandinavia and USA. Frontiers of Entrepreneurship Research, 17. Babson College/Kauffman Entrepreneurship Research Conference, Centre for Entrepreneurial Studies, Babson College, Wellesley.

Bae, T.J., Qian, S., Miao, C., Fiet, J.O. 2014. The relationship between entrepreneurship education and entrepreneurial intentions: A meta-analytic review. Entrepreneurship theory and practice, 38(2), 217-254.

Bastian, B.L., Sidani, Y.M., El Amine, Y. 2018. Women entrepreneurship in the Middle East and North Africa. Gender in Management: An International Journal.

Birley, S. 1988. Female Entrepreneurs - are the really any different? Cranfield School of Management, School Working Paper 5/87 online available at: https://dspace.lib.cranfield.ac.uk/bitstream/1826/439/2/SWP0587.pdf

Caputo, A., Mehtap, S., Pellegrini, M.M., Al-Refai, R. 2016b. Supporting opportunities for female entrepreneurs in Jordan. International Journal of Entrepreneurship and Small Business, 27(2-3), 384-409.

Chang, E.P.C., Memili, E., Chrisman, J.J., Kellermanns, F.W., Chua, J.H. 2009. Venture preparedness and start-up decisions: does family help? A report on Hispanic entrepreneurs in the US. Family Business Review, Vol. 22, No. 3, 279-292.

Cochran, S.L. 2019. What's Gender Got to Do with It? The Experiences of US Women Entrepreneurship Students. Journal of Small Business Management, 57(sup1), 111-129.

Craig, C.S., Douglas, S.P. 2005. International marketing research (3rd ed.). London: John Wiley \& Sons.

Davidsson, P. 2008. The entrepreneurship research challenge. Northampton, MA: Edward Elgar.

De Bruin, A., Brush, C.G., Welter, F. 2007. Advancing a framework for coherent research on women's entrepreneurship. Entrepreneurship theory and practice, 31(3), 323-339.

Díaz-Casero, J.C., Fernández-Portillo, A., Sánchez-Escobedo, M.C., Hernández-Mogollón, R. 2017. The influence of university context on entrepreneurial intentions. In Entrepreneurial Universities, 65-81. Springer, Cham.

Dutta, D.K., Li, J., Merenda, M. 2011. Fostering entrepreneurship: impact of specialization and diversity in education. International Entrepreneurship and Management Journal, 7(2), 163-179.

Elali, W., Al-Yacoub, B. 2016. Factors affecting entrepreneurial intentions among Kuwaitis. World Journal of Entrepreneurship, Management and Sustainable Development.

El-Namaki, M.S.S., Gerritson, J.C.M. 1987. The Entrepreneurial Role of Women in Developing Countries: Entry and Performance Barriers. RVB Research Paper, 7(1). 
Faisal, M.N., Jabeen, F., Katsioloudes, M.I. 2017. Strategic interventions to improve women entrepreneurship in GCC countries. Journal of Entrepreneurship in Emerging Economies.

El-Sokari, H., Van Horne, C., Huang, Z., Al Awad, M. 2013. Entrepreneurship: An Emirati Perspective. The Institute for Social and Economic Research (ISER)-Zayed University, Abu Dhabi.

Fayolle, A., Gailly, B., Lassas-Clerc, N. 2006. Assessing the impact of entrepreneurship education programmes: a new methodology. Journal of European industrial training.

Fayolle, A., Lamine, W., Mian, S., Phan, P. 2020. Effective models of science, technology and engineering entrepreneurship education: current and future research. The Journal of Technology Transfer, 1-11.

Farhangmehr, M., Gonçalves, P., Sarmento, M., McCracken, M., Matlay, H. 2016. Predicting entrepreneurial motivation among university students: The role of entrepreneurship education. Education+ Training.

Fornell, C., Larcker, D.F. 1981. Evaluating structural equation models with unobservable variables and measurement error. Journal of marketing research, 39-50.

Fragoso, R., Rocha-Junior, W., Xavier, A. 2020. Determinant factors of entrepreneurial intention among university students in Brazil and Portugal. Journal of Small Business \& Entrepreneurship, 32(1), 33-57.

Franke, N., Lüthje, C. 2004. Entrepreneurial intentions of business students: A benchmarking study. International Journal of Innovation and Technology Management, 1(03), 269288.

Gaddam, S. 2008. Identifying the relationship between behavioral motives and entrepreneurial intentions: An empirical study based on the perceptions of business management students. The Icfaian Journal of Management Research, VII(5), 35-55.

Gallant, M., Majumdar, S., Varadarajan, D. 2010. Outlook of female students towards entrepreneurship. Education, Business and Society: Contemporary Middle Eastern Issues.

GEM. 2019. GEM 2019 Global report. Retrieved from: https://www.gemconsortium.org/file/open?fileId=50443

Gupta V.K., Turban D.B., Bhave N.M. 2008. The Effect of Gender Stereotype Activation on Entrepreneurial Intentions. Journal of Applied Psychology, 93, 5, 1053-1061.

Hahn, D., Minola, T., Van Gils, A., Huybrechts, J. 2017. Entrepreneurial education and learning at universities: exploring multilevel contingencies. Entrepreneurship \& Regional Development, 29(9-10), 945-974.

Hair Jr, J.F., Hult, G.T.M., Ringle, C., Sarstedt, M. 2017. A primer on partial least squares structural equation modeling (PLS-SEM). Sage Publications.

Hechavarría, D.M., Ingram, A.E. 2019. Entrepreneurial ecosystem conditions and gendered national-level entrepreneurial activity: a 14-year panel study of GEM. Small Business Economics, 53(2), 431-458.

Henseler, J., Ringle, C.M., Sinkovics, R.R. 2009. The use of partial least squares path modeling in international marketing. Advances in International Marketing, 20, 277-320.

Hofstede, G. 2001. Culture's consequences: Comparing values, behaviors, institutions and organizations across nations. Sage publications.

House, R.J., Hanges, P.J., Javidan, M., Dorfman, P.W., Gupta, V. (Eds.). 2004. Culture, leadership, and organizations: The GLOBE study of 62 societies. Sage publications.

Iakovleva, T., Solesvik, M.Z. 2014. Entrepreneurial intentions in post-Soviet economies. International Journal of Entrepreneurship and Small Business, 21(1), 79100 . 
Ibrahim, O.A., Devesh, S., Ubaidullah, V. 2017. Implication of attitude of graduate students in Oman towards entrepreneurship: an empirical study. Journal of Global Entrepreneurship Research, 7(1), 8.

Itani, H., Sidani, Y.M., Baalbaki, I. 2011. United Arab Emirates female entrepreneurs: motivations and frustrations. Equality, Diversity and Inclusion: An International Journal.

Jabeen, F., Das, S.S., Katsioloudes, M.I. 2015. Is family the key? Exploring the motivation and success factors of female Emirati entrepreneurs.

Jabeen, F., Faisal, M.N. 2018. Imperatives for improving entrepreneurial behavior among females in the UAE. Gender in Management: An International Journal.

Jones, C., English, J. 2004. A contemporary approach to entrepreneurship education. Education and Training, 46 (8/9), 416-423.

Karimi, S., Biemans, H.J., Naderi Mahdei, K., Lans, T., Chizari, M., Mulder, M. 2017. Testing the relationship between personality characteristics, contextual factors and entrepreneurial intentions in a developing country. International Journal of Psychology, 52(3), 227-240.

Kautonen, T., Van Gelderen, M., Fink, M. 2015. Robustness of the theory of planned behavior in predicting entrepreneurial intentions and actions. Entrepreneurship theory and practice, 39(3), 655-674.

Keat, O.Y., Selvarajah, C., Meyer, D. 2011. Inclination towards entrepreneurship among university students: An empirical study of Malaysian university students. International Journal of Business and Social Science, 2(4).

Kenny, D.A. 2016. Moderation. Retrieved from: http://davidakenny.net/cm/moderation.htm\#GG

Krejcie, R.V., Morgan, D.W. 1970. Determining sample size for research activities. Educational and Psychological Measurement, 30(3), 607-610.

Krueger, N.F. 2009. The microfoundations of entrepreneurial learning and... education: the experiential essence of entrepreneurial cognition. Handbook of university-wide entrepreneurship education, 35-59.

Kuratko, D.F. 2005. The emergence of entrepreneurship education: Development, trends, and challenges. Entrepreneurship theory and practice, 29(5), 577-597.

Ladd, T., Hind, P., Lawrence, J. 2019. Entrepreneurial orientation, Waynesian self-efficacy for searching and marshaling, and intention across gender and region of origin. Journal of Small Business \& Entrepreneurship, 31(5), 391-411.

Liñán, F., Chen, Y.W. 2009. Development and cross-cultural application of a specific instrument to measure entrepreneurial intentions. Entrepreneurship theory and practice, 33(3), 593-617.

Lüthje, C., Franke, N. 2003. The 'making' of an entrepreneur: testing a model of entrepreneurial intent among engineering students at MIT. R\&d Management, 33(2), 135-147.

MacKenzie, S.B., Podsakoff, P.M. 2012. Common method bias in marketing: Causes, mechanisms, and procedural remedies. Journal of retailing, 88(4), 542-555.

Maden, C. 2015. A gendered lens on entrepreneurship: Women entrepreneurship in Turkey. Gender in Management: An International Journal.

Maina, R.W. 2011. Determinants of entrepreneurial intentions among Kenyan college graduates. KCA Journal of Business Management, 3(2).

Mandrup, M., Jensen, T.L. 2017. Educational Action Research and Triple Helix principles in entrepreneurship education: introducing the EARTH design to explore individuals in Triple Helix collaboration. Triple Helix, 4(1), 1-26. 
Martin, B.C., McNally, J.J., Kay, M.J. 2013. Examining the formation of human capital in entrepreneurship: A meta-analysis of entrepreneurship education outcomes. Journal of business venturing, 28(2), 211-224.

Matlay, H., Jones, C. 2011. Understanding the heterogeneity of entrepreneurship education: going beyond Gartner. Education+ Training.

Mehtap, S., Pellegrini, M.M., Caputo, A., Welsh, D.H. 2017. Entrepreneurial intentions of young women in the Arab world. International Journal of Entrepreneurial Behavior \& Research.

McClelland, D.C. 1961. Achieving society (No. 15). Simon and Schuster.

Mcleod, S. 2016. Social Learning Theory. Retrieved from: https://www.simplypsychology.org/bandura.html

Mcleod, S. 2017. Psychodynamic Theory. Retrieved from: https://www.simplypsychology.org/psychodynamic.html

Moberg, K. 2014. Two approaches to entrepreneurship education: The different effects of education for and through entrepreneurship at the lower secondary level. The International Journal of Management Education, 12(3), 512-528.

Mueller, S.L., Thomas, A.S. 2001. Culture and entrepreneurial potential: A nine country study of locus of control and innovativeness. Journal of business venturing, 16(1), 5175 .

Nabi, G., Liñán, F., Davey, T., Plewa, C., Struwig, M. 2011. Entrepreneurship perceptions and career intentions of international students. Education+ Training.

Nasiru, A., Keat, O.Y., Bhatti, M.A. 2015. Influence of perceived university support, perceived effective entrepreneurship education, perceived creativity disposition, entrepreneurial passion for inventing and founding on entrepreneurial intention. Mediterranean Journal of Social Sciences, 6(3), 88.

Neneh, B.N. 2019. From entrepreneurial intentions to behavior: The role of anticipated regret and proactive personality. Journal of Vocational Behavior, 112, 311-324.

Norena-Chavez, D., Guevara, R. 2020. Entrepreneurial Passion and Self-Efficacy as Factors Explaining Innovative Behavior: A Mediation Model. International Journal of Economics and Business Administration, 8(3), 352-373. DOI: 10.35808/ijeba/522.

Norena-Chavez, D. 2020. The Mediation Effect of Innovative Behavior on the Relationship Between Entrepreneurial Self-Efficacy and Entrepreneurial Intention. International Journal of Economics and Business Administration, 8(4), 238-252. DOI: $10.35808 / \mathrm{ijeba} / 583$.

Nowiński, W., Haddoud, M.Y., Lančarič, D., Egerová, D., Czeglédi, C. 2019. The impact of entrepreneurship education, entrepreneurial self-efficacy and gender on entrepreneurial intentions of university students in the Visegrad countries. Studies in Higher Education, 44(2), 361-379.

Omoruyi, E.M.M., Olamide, K.S., Gomolemo, G., Donath, O.A. 2017. Entrepreneurship and economic growth: Does entrepreneurship bolster economic expansion in Africa. J Socialomics, 6(4), 219.

Oosterbeek, H., Van Praag, M., Ijsselstein, A. 2010. The impact of entrepreneurship education on entrepreneurship skills and motivation. European economic review, 54(3), 442-454.

Otache, I., Umar, K., Audu, Y., Onalo, U. 2019. The effects of entrepreneurship education on students' entrepreneurial intentions. Education+ Training.

Pallant, J. 2013. SPSS survival manual: A step by step guide to data analysis using SPSS for windows ( $4^{\text {th }}$ ed.). England, UK: McGraw Hill Open University Press. 
Peterman, N.E., Kennedy, J. 2003. Enterprise education: Influencing students' perceptions of entrepreneurship. Entrepreneurship theory and practice, 28(2), 129-144.

Peterson, J. 2020. Gender differences. Retrieved from: https://www.youtube.com/c/jordanpetersonvideos

Peterson, R.T., Limbu, Y. 2010. Student characteristics and perspectives in entrepreneurship courses: a profile. Journal of Entrepreneurship Education, 13, 65.

Pruett, M., Shinnar, R., Toney, B., Llopis, F., Fox, J. 2009. Explaining entrepreneurial intentions of university students: a cross-cultural study. International Journal of Entrepreneurial Behavior \& Research.

Raghuvanshi, J., Agrawal, R., Ghosh, P.K. 2017. Analysis of barriers to women entrepreneurship: The DEMATEL approach. The Journal of Entrepreneurship, 26(2), 220-238.

Reardon, K.K. 1991. Persuasion in practice. Sage.

Ronstadt, R. 1985. The Educated Entrepreneurs: A New Era of Entrepreneurial Education is Beginning. American Journal of Small Business, 11(4), 37-54.

Salami, S.O. 2007. Influence of culture, family and individual differences on choice of gender-dominated occupations among female students in tertiary institutions. Women in Management Review.

Sánchez, J.C. 2013. The impact of an entrepreneurship education program on entrepreneurial competencies and intention. Journal of small business management, 51(3), 447-465.

Sandhu, M.S., Sidique, S.F., Riaz, S. 2011. Entrepreneurship barriers and entrepreneurial inclination among Malaysian postgraduate students. International journal of entrepreneurial behavior \& research.

Schmutzler, J., Andonova, V., Diaz-Serrano, L. 2019. How context shapes entrepreneurial self-efficacy as a driver of entrepreneurial intentions: A multilevel approach. Entrepreneurship Theory and Practice, 43(5), 880-920.

Scott, M.G., Twomey, D.F. 1988. The long-term supply of entrepreneurs: students' career aspirations in relation to entrepreneurship. Journal of small business management, 26(4), 5.

Shi, L., Yao, X., Wu, W. 2019. Perceived university support, entrepreneurial self-efficacy, heterogeneous entrepreneurial intentions in entrepreneurship education. Journal of Entrepreneurship in Emerging Economies.

Shapero, A., Sokol, L. 1982. The social dimensions of entrepreneurship. Encyclopedia of entrepreneurship, 72-90.

Sobel, R.S. 2008. Testing Baumol: Institutional quality and the productivity of entrepreneurship. Journal of Business Venturing, 23(6), 641-655.

Solesvik, M.Z. 2013. Entrepreneurial motivations and intentions: investigating the role of education major. Education+ Training.

Son, L., Noja, G.G., Ritivoiu, M., Tolteanu, R. 2013. Education and economic growth: An empirical analysis of interdependencies and impacts based on panel data. Timisoara Journal of Economics and Business 6(19), 39-54.

Son, L., Noja, G.G. 2013. The role of the human capital and investment in human capital within the sustainable socio-economic development. How labour force migration affects competitiveness? Theoretical and Applied Economics, 18(10(587)), 111-126.

Stoica, O., Roman, A., Rusu, V.D. 2020. The Nexus between Entrepreneurship and Economic Growth: A Comparative Analysis on Groups of Countries. Sustainability, 12(3), 1186.

Tabachnick, B.G., Fidell, L.S. 2007. Using multivariate statistics (5th edn). Boston, MA: Pearson Education. 
Thaiss, H.A. 2015. Entrepreneurial motivations of women: Evidence from the United Arab Emirates. International Small Business Journal, 33(5), 562-581.

The Global Economy. 2020. Retrieved from: https://www.theglobaleconomy.com/Oman/Female unemployment/

Turker, D., Selcuk, S.S. 2009. Which factors affect entrepreneurial intention of university students? Journal of European industrial training.

Turner, T., Gianiodis, P. 2018. Entrepreneurship unleashed: Understanding entrepreneurial education outside of the business school. Journal of Small Business Management, 56(1), 131-149.

Valliere, D., Peterson, R. 2009. Entrepreneurship and economic growth: Evidence from emerging and developed countries. Entrepreneurship \& Regional Development, 21(56), 459-480.

Venkatraman, N. 1994. IT-enabled business transformation: from automation to business scope redefinition. Sloan management review, 35, 73-73.

Venugopal, V. 2016. Investigating women's intentions for entrepreneurial growth. International Journal of Gender and Entrepreneurship.

Walter, S.G., Block, J.H. 2016. Outcomes of entrepreneurship education: An institutional perspective. Journal of Business Venturing, 31(2), 216-233.

Walter, S.G., Dohse, D. 2012. Why mode and regional context matter for entrepreneurship education. Entrepreneurship \& Regional Development, 24(9-10), 807-835.

Wang, Y., Verzat, C. 2011. Generalist or specific studies for engineering entrepreneurs? Journal of Small Business and Enterprise Development.

Welter, F., Smallbone, D. 2011. Institutional perspectives on entrepreneurial behavior in challenging environments. Journal of Small Business Management, 49(1), 107-125.

Zhao, H., Seibert, S.E., Hills, G.E. 2005. The mediating role of self-efficacy in the development of entrepreneurial intentions. Journal of applied psychology, 90(6), 1265. 